\title{
APPLICABLE LAW IN MATRIMONIAL PROPERTY REGIME DISPUTES
}

\author{
Doc. dr. Neža Pogorelčnik Vogrinc*
}

\author{
UDK: 347.626 \\ https://doi.org/10.30925/zpfsr.40.3.5 \\ Ur.: 02. listopada 2019. \\ Pr.: 16. prosinca 2019. \\ Prethodno priopćenje
}

\begin{abstract}
Summary
The paper presents the regulation of the applicable law as determined in Council Regulation (EU) 2016/1103 of 24 June 2016 implementing enhanced cooperation in the area of jurisdiction, applicable law and the recognition and enforcement of decisions in matters of matrimonial property regimes. It concludes that the new EU arrangement has made it easier for spouses to determine the applicable law and evaluates the suitability of the connecting factors provided by Regulation 2016/1103. The paper also challenges the examination of these connecting factors as of the time of the conclusion of the marriage and assumes that their exclusion under exceptional circumstances is difficult to achieve. It compares the connecting factors with those provided by Slovenian and Croatian private international law in theory, and provides practical examples of the differences resulting from the new European arrangement. The paper further examines the hypothesis that the possibility of agreement on the choice of law will cause many problems in practice, and provides possible solutions. Throughout the paper, the system established by Regulation 2016/1103 is compared with other European regulations and the relevant case law of the CJEU, but the author primarily focuses on the changes in Slovenian and Croatian case law caused by the application of Regulation 2016/1103.
\end{abstract}

Keywords: matrimonial property regime; applicable law; Regulation 2016/1103; international private law; choice-of-law agreement.

* Neža Pogorelčnik Vogrinc, Ph.D., Assistant Professor, Faculty of Law, University of Ljubljana; neza.pogorelcnik@pf.uni-lj.si.

This paper has been co-funded by the European Union's Justice Programme (2014-2020) Project PSEFS - Personalized Solution in European Family and Succession Law n. 800821-JUSTAG-2017/JUST-JCOO-AG-2017. The content of this document represents the views of the author only and is his/her sole responsibility. The European Commission does not accept any responsibility for use that may be made of the information it contains. 


\section{INTRODUCTION}

Family relations and the regulation thereof is a sensitive matter. While they are primarily important to individuals, the state's relationship to family relations is delicate as well. The progressiveness of such regulation depends in particular on how developed a society is and on the climate in each respective state. European Union (EU) Member States ${ }^{1}$ range across a broad spectrum as regards both progressiveness and social climate, which became evident (yet again) in the procedure for formulating and adopting a single European legal framework for the property consequences of marriage and registered partnerships.

Due to uncertainty about matrimonial property regimes, which had posed problems for cross-border spouses exercising their rights, the need to adopt European legislation $^{2}$ in this field was made a priority for the first time in the 1998 Vienna Action Plan. ${ }^{3}$ Various activities ${ }^{4}$ followed, which in March 2011 ultimately resulted in the adoption of the Proposal for a Council Regulation on jurisdiction, applicable law and the recognition and enforcement of decisions in matters of matrimonial property regimes $(\mathrm{COM}(2011) 126$ final) and the Proposal for a Council Regulation on jurisdiction, applicable law and the recognition and enforcement of decisions regarding the property consequences of registered partnerships (COM(2011) 127 final). Since they fall within the domain of family law, the proposals would have had to be confirmed by the Council by a unanimous vote after consultation with the Parliament (Article 81/III of the Treaty on the Functioning of the European Union ${ }^{5}$ ), but after almost two years of debate and fierce opposition from some Member States (Poland and Hungary in particular), the Council decided in December 2015 that consensus was not achievable. Immediately thereafter, several Member States expressed willingness to establish enhanced cooperation on this matter. In June 2016 the Council approved ${ }^{6}$ that and then immediately adopted Council Regulation

1 For an overview of the legal arrangements in some non-EU countries, see Scherpe, J. M. (ed.), Marital Agreements and Private Autonomy in Comparative Perspective, Oxford, Hart Publishing, 2012.

2 Before that, the Convention Relating to Conflicts of Laws with regard to the Effects of Marriage on the Rights and Duties of the Spouses in their Personal Relationship with regard to their Estates of 17 July 1905 and the Convention on the Law Applicable to Matrimonial Property Regimes of 14 March 1978 had been adopted in the framework of the Hague Conference on Private International Law.

3 Proposal for a Council Regulation on jurisdiction, applicable law and the recognition and enforcement of decisions in matters of matrimonial property regimes $\operatorname{COM}(2011) 126$ final, 2011/0059 (CNS), p. 2.

4 There were several prior steps on this path, including the Programme of measures for implementation of the principle of mutual recognition of decisions in civil and commercial matters (OJ L 12 of 15 January 2001), the Hague Programme (OJ L 53 of 3 March 2005) adopted in November 2004, the Stockholm Programme adopted in December 2009, and the EU Citizenship Report of 2010 (COM(2010) 603). For more, see Proposal for a Council Regulation on jurisdiction, applicable law and the recognition and enforcement of decisions in matters of matrimonial property regimes $\mathrm{COM}(2011) 126$ final, 2011/0059 (CNS), p. 2.

5 OJ EU C 326.

6 Council Decision (EU) 2016/954, OJ L 159/16 of 16 June 2016. 
(EU) 2016/1104 of 24 June 2016 implementing enhanced cooperation in the area of jurisdiction, applicable law and the recognition and enforcement of decisions in matters of the property consequences of registered partnerships ${ }^{7}$ (Regulation 2016/1104) and Council Regulation (EU) 2016/1103 of 24 June 2016 implementing enhanced cooperation in the area of jurisdiction, applicable law and the recognition and enforcement of decisions in matters of matrimonial property regimes ${ }^{8}$ (Regulation 2016/1103). The enhanced cooperation features 18 countries: Belgium, Bulgaria, the Czech Republic, Germany, Greece, Spain, France, Croatia, Italy, Luxembourg, Malta, the Netherlands, Austria, Portugal, Slovenia, Finland, Sweden, and Cyprus. For them, both Regulations are binding, directly applicable, and completely replace the relevant national rules on private international law. The remaining EU Member States continue to apply national private international law to matrimonial property regimes. They may join the enhanced cooperation at any time in the future, but in order to do so they must accept both regulations. ${ }^{9}$ Only Estonia has so far announced a willingness to join, whereas cooperation from any of the other countries is not expected - at least for now. ${ }^{10}$ The most frequently cited concern of the non-participating states is that under Regulations 2016/1104 and 2016/1103 a state that does not recognise same-sex marriage and/or registered partnerships between same-sex (or heterosexual) couples would have to recognise such unions concluded in other Member States. ${ }^{11}$ There are safeguards against that in Recital 64 of Regulation 2016/1103 (and Recital 64 of Regulation 2016/1104; see also Recital 21 of both Regulations), which stipulates that the recognition and enforcement of a decision on the matrimonial property regime thereunder should not in any way imply recognition of the marriage underlying the matrimonial property regime that gave rise to the decision. Consequently, the participating countries are not required by Regulation 2016/1103 to transpose into national law forms of matrimony that they do not recognise in their national law, nor to recognise a personal status thereunder. Alas, encountering marital forms unrecognised in domestic legislation is inevitable. One source of confusion ${ }^{12}$ is the

7 OJ EU L 183 of 8 July 2016.

8 OJ EU L 183 of 8 July 2016.

9 Recital 7 of Council Decision (EU) 2016/954 of 9 June 2016. See also Valentová, L., Property regimes of spouses and partners in new EU Regulations - jurisdiction, prorogation and choice of law, De Gruyter, ICLR, Vol. 16, 2/2016, p. 226, and Rudolf, C., Premoženjska razmerja med zakonci $\mathrm{v}$ mednarodnem zasebnem pravu (Matrimonial property regimes in private international law), Podjetje in delo, Vol. XLIV, 6-7/2018, p. 954.

10 In questionnaires regarding Regulations 2016/1103 and 2016/1104 whose answers are collected in Family Property and Succession in EU Member States National Reports on the Collected Data, the rapporteurs from Hungary, Poland, Romania, Lithuania, and Latvia said their countries would not join the enhanced cooperation, whereas the rapporteurs from Denmark, Ireland, Slovakia, and the United Kingdom did not answer this question.

11 See the individual country reports in Family Property and Succession in EU Member States National Reports on the Collected Data.

12 See Kunda, I., Novi međunarodnoprivatnopravni okvir imovine bračnih i registriranih partnera u Europskoj uniji: polje primjene i nadležnost, Zagreb, Hrvatska pravna revija, Vol. 19, 3/2019, p. 29. 
absence of a definition of marriage in Regulation 2016/1103 (Recital 17), ${ }^{13}$ which is why each Member State uses its own definition thereof. Recognition of a marriage or registered partnership concluded abroad that a Member State does not recognise therefore remains an open issue. The problem is not just recognition of unions between same-sex partners, which is the biggest (and very explicit) concern of states that have not joined the enhanced cooperation. It also (for example in Slovenia) concerns recognising a partnership registered by a heterosexual couple abroad. Slovenian law does not provide for such a partnership, which raises the question of whether such should be treated as a marriage or registered partnership, or whether a court should resort to the exception - alternative jurisdiction (Article 9 of Regulations 2016/1104 and 2016/1103) - and decline jurisdiction if it decides that such a partnership cannot be recognised in a specific case for the purposes of matrimonial property regime proceedings. ${ }^{14}$ This issue will have to be addressed by case law; absent a response from the Court of Justice of the European Union (CJEU), the case law of the Member States will probably produce conflicting solutions.

As of 29 January 2019, Regulation 2016/1103 is thus applicable to matrimonial property regimes - including with regard to the applicable law - in the Member States participating in the enhanced cooperation. The Regulation, for example, gives (future) spouses the option to choose the applicable law, and it provides rules to determine which law shall apply in the event the spouses do not agree on the choice of law. This paper explores whether the new EU arrangement has made it easier for spouses to determine the applicable law and evaluates the suitability of the connecting factors provided by Regulation 2016/1103. It also challenges the examination of these connecting factors as of the time of the conclusion of the marriage; they may be excluded under exceptional circumstances, but the paper assumes that the conditions for exclusion are difficult to achieve. It compares the connecting factors with those provided by Slovenian and Croatian private international law in theory, and provides practical examples of differences resulting from the new European arrangement. The paper further examines the hypothesis that the possibility of agreement on the choice of law will cause many problems in practice, and provides possible solutions. Throughout the paper, the system established by Regulation 2016/1103 is compared with other European regulations and the relevant case law of the CJEU. Several authors (e.g. Oprea, Party autonomy and the law applicable to the matrimonial property regimes in Europe - see the list of literature for more; Damascelli, Applicable law, jurisdiction, and recognition of decisions in matters relating to property regimes of spouses and partners in European and Italian private international law; Dolžan, Uredbi (EU) glede premoženjskopravnih razmerij za mednarodne pare - kolizijska pravila; Kunda, Novi međunarodnoprivatnopravni okvir imovine bračnih i registriranih partnera u Europskoj uniji: polje primjene i nadležnost; Poretti, Odlučivanje o imovinskim odnosima bračnih drugova u ostavinskim postupcima sukladno Uredbi 2016/1103

13 Regulation 2016/1104, on the other hand, defines the term registered partnership.

14 Denial of jurisdiction is not possible when the parties have obtained a divorce, legal separation, or marriage annulment that is capable of being recognised in the Member State (participating in the enhanced cooperation) of the court at which the procedure is ongoing (Article 9/III of Regulation 2016/1103). 
o bračnoimovinskom režimu) have previously dealt with the applicable law under Regulation 2016/1103, but there are no works specifically dealing with the impact of Regulation 2016/1103 on the application of private international law on the matrimonial property regimes of Croatia and Slovenia.

\section{NATIONAL PRIVATE INTERNATIONAL LAW}

Regulation 2016/1103 does not determine in which cross-border disputes it is applicable. ${ }^{15}$ In countries participating in the enhanced cooperation it replaces the relevant provisions of private international law regardless of the country of origin of the international element that defines this as a cross-border dispute. The regulation is thus not applicable only in disputes with an element from another country participating in the enhanced cooperation; it is also applicable in disputes with an element from other EU Member States and in disputes with an element from third countries. In Slovenia, for example, it completely replaces ${ }^{16}$ the relevant provisions of the Private International Law and Procedure Act ${ }^{17}$ (Zakon o mednarodnem zasebnem pravu in postopku - ZMZPP). In Croatia, the Act Concerning the Resolution of Conflicts of Laws with the Provisions of Other Countries in Certain Matters ${ }^{18}$ (Zakon o rješavanju sukoba zakona s propisima drugih zemalja u ođređenim odnosima - ZRSZPDZ) was in force until 29 January 2019, when it was replaced by the Private International Law $\mathrm{Act}^{19}$ (Zakon o međunarodnom privatnom pravu - ZMPP). Whereas the former was almost identical to the Slovenian ZMZPP, in the ZMPP the Croatian legislature took a different route regarding the regulation dealt with in this article. Since Regulation 2016/1103 applies to matrimonial property regimes in all cross-border disputes, there is no need for a national regulation on this matter. The Croatian ZMPP thus refers to Regulation 2016/1103 concerning the applicable law and jurisdiction in such disputes (just as it defers to Regulation 2016/1104 for disputes concerning the property consequences of registered partnerships) and does not have its "own" provisions concerning these matters.

\section{THE REGULATORY FRAMEWORK OF CONFLICT-OF-LAW RULES}

When a judge determines that he or she has (international) jurisdiction in a dispute with an international element, he or she then determines which country's substantive law to apply in the ruling. With regard to the law governing (personal and) matrimonial property, the ZMZPP (Article 38) determined nationality as the primary

15 Cf., for example, Article 3 of Regulation (EC) No. 1896/2006 of the European Parliament and of the Council of 12 December 2006 creating a European order for payment procedure, OJ EU L 399 of 30 December 2006.

16 An exception exists for the provisions regarding the applicable law. These will continue to be used for a while. See the section "The ratione temporis of Regulation 2016/1103".

17 OG RS 56/99 as amended.

18 OG Croatia 53/91 and 88/01.

19 OG Croatia 101/17. 
connecting factor. The primary applicable law is therefore the law of the state of which (both) spouses are nationals (lex patriae, lex nationalis). This is a changeable yet fairly stable connecting factor that is far more difficult to change than (temporary or permanent) residence. If the spouses are nationals of different states, the law of the state in which they have permanent residence applies (lex domicilii). If the spouses have neither the same nationality nor permanent residence in the same state, the law of the state in which they both had their last permanent residence applies; absent that, the law that is most closely connected to the relationship applies (closest connection). For the latter, it is necessary to consider all of the circumstances of the case in question, e.g. the nationality and residence of the parties, their language, etc. The competent court decides which law is most closely connected to the relationship. The legal framework established by the Croatian ZRSZPDZ was the same, only that instead of the last connecting factor - the closest connection - it referred to the application of Croatian law (Article 36). The almost identical provisions of both laws are an indication of their common roots. In both countries the Yugoslav Act Concerning the Resolution of Conflicts of Laws with the Provisions of Other Countries in Certain Matters (Zakon o ureditvi kolizije zakonov s predpisi drugih držav v določenih razmerjih - ZUKZ $)^{20}$ had previously been in force, and both countries subsequently modelled their laws on the resolution of conflicts of laws on (inter alia) the matrimonial property regimes on the Yugoslav precursor.

Article 38 of the ZMZPP does not determine at which point in time the existence of connecting factors is examined for the purposes of determining conflict-of-law rules, but these are considered ${ }^{21}$ changeable connecting factors that refer to the moment of examination, i.e. the initiation of court proceedings. If during the course of the marriage a circumstance changes (e.g. the spouses acquire or lose nationality or move), this results in a change in the law that would apply if a dispute concerning matrimonial property were to be examined by a court (a changeable factor). ${ }^{22}$

Regulation 2016/110323 (Article 26/I) determines connecting factors to be

20 OG SFRJ 43-525/82 as amended.

21 Ilešič, M., Polajnar-Pavčnik, A., Wedam-Lukić, D., Mednarodno zasebno pravo, komentar zakona, Ljubljana, Časopisni zavod Uradni list Republike Slovenije, 1992, p. 71.

22 Geč Korošec, M., Mednarodno zasebno pravo, Druga knjiga - posebni del, Ljubljana, Uradni list Republike Slovenije, 2002, p. 57. For details, see Mednarodno zasebno pravo, komentar zakona, Ilešič, M., Polajnar-Pavčnik, A., Wedam-Lukić, D., op. cit., p. 71. The same applied to the previously valid Croatian ZRSZPDZ.

23 The law designated by Regulation 2016/1103 as applicable applies even if it is the law of a state that does not participate in the enhanced cooperation (Article 20) - the principle of universal application. Such an arrangement has been used in certain other EU regulations - cf. Article 20 of Regulation (EU) No 650/2012 of the European Parliament and of the Council of 4 July 2012 on jurisdiction, applicable law, recognition and enforcement of decisions and acceptance and enforcement of authentic instruments in matters of succession and on the creation of a European Certificate of Succession (OJ L 201 of 27 July 2012; Regulation 650/2012 on succession), Article 4 of Council Regulation (EU) No. 1259/2010 of 20 December 2010 implementing enhanced cooperation in the area of the law applicable to divorce and legal separation (Regulation Rome III), OJ L 343/10 of 29 December 2010, and Article 2 of Regulation (EC) No. 593/2008 of the European Parliament and of the Council of 17 June 2008 on the law applicable to contractual obligations (Regulation Rome I), OJ L 177 of 4 July 2008. 
considered in the choice of conflict-of-law rules that are significantly different than those provided by the ZMZPP. The Council has moved away from nationality as the typical connecting factor in continental law ${ }^{24}$ and determined common habitual residence after the conclusion of the marriage as the first relevant factor. This is a fixed, unchangeable connecting factor that subsequent changes (e.g. the relocation of the common habitual residence of the spouses) will not affect, nor do such changes therefore affect the choice of applicable law. The country of common residence should be identified, which makes it possible to use this connecting factor to determine the applicable law even if the spouses have different habitual residences within a single state. ${ }^{25}$ This raises the question of how long after the conclusion of the marriage a common habitual residence must be established in order for it to constitute the first connecting factor. Is this a connecting factor if the married spouses settled in the same Member State a month or a year after marriage? Regulation 2016/1103 does not address this, leaving it up to case law; in order to aid case law, Recital 49 only determines that the first common habitual residence shortly after marriage should constitute the first criterion. In theory there have been proposals that there should be a period of several months after the conclusion of the marriage during which this condition must be fulfilled, ${ }^{26}$ but some are also of the opinion that the period that should count as the first residence after the conclusion of the marriage should not be restricted..$^{27}$ In my opinion, it is impossible to specify a time period after the conclusion of the marriage during which the first common habitual residence may be established. In each specific case the decision hinges on the circumstances and it is in the hands of the court, but the author disagrees with the notion that such a condition may be fulfilled at any time after the conclusion of the marriage (e.g. that spouses who got married in their youth do not create the first common habitual residence until after retirement, thereby achieving the first connecting factor for the purposes of the choice of law). Since it is assumed that in most cases spouses will start living together after marriage (or at least in the same country), other connecting factors will be used only rarely in determining the applicable law.

If, after marrying, the spouses do not have a common habitual residence in the same country or do not live long or intensely enough in any other country to establish habitual residence there, their matrimonial property regime is subject to the law of the state whose common nationality the spouses had at the time of the conclusion of the marriage. This is a more stable connecting factor than the first one, and it is easier to identify. National law and international conventions are used to identify a person's nationality (Recital 50). If the spouses do not have a common nationality at the time of the conclusion of the marriage, this connecting factor cannot be considered. The result

24 Schulz, R., Choice of law in relation to matrimonial property in the $21^{\text {st }}$ Century, Journal of Private International Law, Vol. 15, 1/2019, pp. 10-11.

25 Dolžan, J., Uredbi (EU) glede premoženjskopravnih razmerij za mednarodne pare - kolizijska pravila, Ljubljana, Odvetnik, Vol. 90, 2/2019, p. 111.

26 Ibid, p. 112. See also Rudolf, C., op. cit., p. 960.

27 Damascelli, D., Applicable law, jurisdiction, and recognition of decisions in matters relating to property regimes of spouses and partners in European and Italian private international law, Trusts \& Trustees, Vol. 0, 0/2018, p. 4. 
is the same if at the time of the conclusion of the marriage the spouses have multiple common nationalities (subject mixtae), which is in line with the CJEU's position on the equality of nationalities. ${ }^{28}$ This is a different approach than that provided by the ZMZPP. For a Slovenian national with multiple nationalities, the ZMZPP, for example, stipulates that for the purposes of the application of the ZMZPP they are considered as having only Slovenian nationality, which is underpinned by the notion that domestic law provides the best legal certainty for nationals of that state. ${ }^{29}$ If a person who is not a Slovenian national has multiple nationalities, for the purposes of the ZMZPP he or she is regarded as being a national of the state he or she is a national of and where he or she has permanent residence, ${ }^{30}$ if such a person does not have permanent residence in any state whose nationality he or she has, he or she is regarded as being a national of the state whose nationality he or she has and with which he or she has the closest links (Article 10). The same arrangement, only for the benefit of Croatian nationality, is provided by the Croatian ZMPP (Article 3) and its predecessor, the ZRSZPDZ (Article 11).

If spouses do not have a common nationality at the time of the conclusion of the marriage or have more than one common nationality, their matrimonial property regime is subject to the law of the state with which, all circumstances considered, both spouses have the closest connection as of the time of the conclusion of the marriage. ${ }^{31}$ Regulation 2016/1103 does not provide guidance on when closest links are deemed to have been established. ${ }^{32}$ In each specific case all of the actual and legal circumstances of the spouses as of the conclusion of the marriage are considered: nationality, religion, language, location of assets, etc., which are determined by the competent court. The moment of the conclusion of the marriage is considered the relevant point for the examination of the closest connection. This is an unchangeable factor that determines which circumstances at a specific moment in the past must be considered. ${ }^{33}$ Subsequent changes (nationality, residence, etc.) do not affect this connecting factor, and the applicable law may change only by way of the spouses concluding an agreement on the choice of law.

28 Marino, S., Strengthening the European civil judicial cooperation: the patrimonial effects of family relationships, Madrid, Cuadernos de Derecho Transnacional, Vol. 9, 1/2017, p. 280.

29 Geč Korošec, M., Mednarodno zasebno pravo, Prva knjiga - splošni del, Ljubljana, Uradni list Republike Slovenije, 2001, p. 88.

30 Loc. cit. It is assumed that a foreigner with multiple nationalities has the closest connection to the state in which he or she has permanent residence.

31 In the event of multiple common nationalities, Regulation 2016/1103 invokes the closest connection as well as the first habitual common residence as connecting factors (Article 26/II), but considering the cascading relationship between them (assuming that identification of the nationality of the spouses was carried out), the latter obviously did not exist.

32 Poretti, P., Odlučivanje o imovinskim odnosima bračnih drugova u ostavinskim postupcima sukladno Uredbi 2016/1103 o bračnoimovinskom režimu, Rijeka, Zbornik Pravnog fakulteta Sveučilišta u Rijeci, Vol. 38, 1/2017, p. 463, believes that the cause of the openness is that this connecting factor may be used for the bulk of cases in which neither the first nor the second connecting factor can be used.

33 Geč Korošec, M., Mednarodno ..., Prva knjiga ..., cit., p. 115, sees this as being intended primarily for the protection of legal certainty, which should be outwardly evident. 
Once determined in such manner, the law applies to the spouses' entire property, regardless of whether it is located in multiple countries, whether or not these countries participate in the enhanced cooperation and whether or not they are EU Member States. It also applies notwithstanding the type of property, which provides legal certainty for the parties and prevents the fragmentation of the matrimonial property regime (Recital 43).

However, reference (regarding all connecting factors) to the moment of the conclusion of the marriage (the second and third connecting factors) or the time after the conclusion of the marriage (the first connecting factor) has an important shortcoming. Even in the event of subsequent significant life changes, during the course of court proceedings the spouses may no longer have a connection to the state whose law will apply. For example, after getting married a German man and Slovenian woman move to Rome for a year due to the wife's training. They then move to Austria, where they live for the next 20 years until they divorce. In a matrimonial property regime procedure, the court of jurisdiction will be in Austria (Article 6/a of Regulation 2016/1103), which will have to apply Italian law (Article 26/I(a) of Regulation 2016/1103), even though the spouses do not (any longer) have a connection to Italy.

To address such situations, Regulation 2016/1103 provides an escape clause. The court can avoid applying the law of the state of first habitual common residence after the conclusion of the marriage under certain conditions (Article 26/III). ${ }^{34}$ Such a solution is possible only when proposed to the court by one of the spouses. He or she must demonstrate that the last habitual residence lasted longer than the first, whereby the court will examine whether it was indeed significantly longer. He or she must also demonstrate the existence of past spousal conduct such that it provides evidence of his or her reference to the law of that state, which is difficult if the other spouse opposes the application of this law. If the other spouse agrees with the application of this law, he or she may actively demonstrate his or her past conduct in this direction, but his or her (explicit) consent to the use of this exception is not required. This exception from the principle of permanence can thus be applied to avoid the impractical application of a law not connected to the dispute; however, it is possible only in specific court procedures when permitted by the court. In the above-mentioned case, Austrian law will therefore be applied provided one of the spouses proposes its application and the conditions are satisfied (and it is possible to determine with certainty the existence of a significantly longer residence in Austria). ${ }^{35}$

\subsection{Examples}

A) German nationals move to Slovenia in 2015 and get married. In October 2019 they divorce. The (ex) husband then moves to Germany and the (ex) wife

34 Poretti sees the application of this provision as creating the possibility of using the law of the same state for both succession and matrimonial property regime disputes between (former) spouses. For details, see Poretti, P., op. cit., p. 464.

35 This creates problems with ex tunc application of the thusly chosen law and the impact on thirdparty rights, but that is beyond the scope of this paper. 
stays in Slovenia. The husband wishes to initiate proceedings for the division of the matrimonial property. Which law will be applied?

This paper does not deal with issues concerning international jurisdiction. But since it is impossible to determine the applicable law without determining international jurisdiction, the subsequent examples also provide solutions for that. In this specific case, the court of (international) jurisdiction is in Slovenia under Regulation 2016/1103 (because the court procedure was initiated (on or) after 29 January 2019 - see the next section) (Article 6/b).

If the ZMZPP is applied, the applicable law is determined pursuant to Article 38/I: the law of the state of which the spouses are nationals is applied, which means that German law ${ }^{36}$ will be applied.

If Regulation 2016/1103 is applied, under Article 26/I(a) the applicable law is the law of the state in which the spouses had their first common habitual residence, in this case Slovenian law.

B) A Slovenian national and a German national settle in Slovenia, where they marry. They divorce in October 2019. The German (ex) wife then moves to Germany and the Slovenian (ex) husband remains in Slovenia. The husband wants to initiate proceedings for the division of the matrimonial property. Which law will be applied?

Pursuant to Regulation 2016/1103 (because court proceedings were initiated (on or) after 29 January 2019 - see the next section), the court in Slovenia has (international) jurisdiction (Article 6/b).

If the ZMZPP is applied, the applicable law is determined pursuant to Article 38/III because the (former) spouses are nationals of different states and do not have residence in the same state. The dispute must be resolved according to the law of the state where they had their last common residence - i.e. Slovenian law.

If Regulation 2016/1103 is applied, the law applicable to the matrimonial property will be the law of the state in which the spouses had their first common habitual residence after the conclusion of the marriage - i.e. Slovenian law.

C) Two Slovenian nationals move to Austria, where they marry. In October 2019 they divorce, whereupon the (ex) husband moves back to Slovenia and the (ex) wife to Germany. The wife wants to initiate proceedings for the division of the matrimonial property. Which law will apply?

Pursuant to Regulation 2016/1103 (because court proceedings were initiated (on or) after 29 January 2019 - see the next section), the court in Slovenia has (international) jurisdiction (Article 6/c).

If the ZMZPP is applied, since they have a common nationality, the dispute is resolved using the law of the state of which the spouses are nationals (Article 38/I) i.e. Slovenian law.

If Regulation 2016/1103 is applied, the law applicable to the matrimonial property will be the law of the state in which the spouses had their first common habitual residence after the conclusion of the marriage - i.e. Slovenian law.

D) Two nationals of the United States move to Slovenia, where they marry.

36 The solution would have been the same under the old Croatian ZRSZPDZ if Slovenia were replaced with Croatia. The same applies to all subsequent examples. 
In October 2019 they divorce but both stay in Slovenia. The wife wants to initiate proceedings for the division of the matrimonial property. Which law will apply?

Pursuant to Regulation 2016/1103 (because court proceedings were initiated (on or) after 29 January 2019 - see the next section), the court in Slovenia has (international) jurisdiction (Article 6/a).

If the ZMZPP is applied, since the spouses have common nationality, the dispute is resolved using the law of the state of which the spouses are nationals (Article 38/I) - i.e. United States law.

If Regulation 2016/1103 is applied, the applicable law will be the law of the state in which the spouses had their first common habitual residence after the conclusion of the marriage - i.e. Slovenian law.

E) A Slovenian national and a German national settle in Slovenia, where they marry. After a year they move to Austria, where they live another year and a half. In October 2019 they divorce, whereupon the (ex) wife moves to Germany and the (ex) husband to Slovenia. The wife wants to initiate proceedings for the division of the matrimonial property. Which law will apply?

Pursuant to Regulation 2016/1103 (because court proceedings were initiated (on or) after 29 January 2019 - see the next section), the court in Slovenia has (international) jurisdiction (Article 6/c).

If the ZMZPP is applied, due to the non-existence of connecting factors under Article 38/I, II, the law of the state of the last common residence applies (Article 38/ III) - i.e. Austrian law.

If Regulation 2016/1103 is applied, the applicable law will be the law of the state in which the spouses had their first common habitual residence after the conclusion of the marriage - i.e. Slovenian law. If one of the spouses proposes and both spouses invoke Austrian law, the court may apply Austrian law if it decided that residence in Austria lasting a year and a half is significantly longer than a one-year residence in Slovenia.

Comment:

In all of the above cases, the essential element in choosing the right answer as to which law applies is that Slovenian courts have international jurisdiction. This occurs when the (former) spouses have habitual residence in Slovenia at the time the court is seised, when they last had common residence in Slovenia and one of them still resides there, when the defendant has habitual residence in Slovenia at the time the court is seised, or when the spouses are Slovenian nationals at the time the court is seised. Connecting factors are used in cascading order (Article 6 of Regulation 2016/1103), but notwithstanding how the international jurisdiction of Slovenian courts is determined, the answer with regard to which law applies is the same.

Regulation 2016/1103 applies (provided marriage was concluded on or after 29 January 2019 - see the next section) regardless of which state the "foreign" element in the dispute comes from. In disputes that continue to apply national private international law, bilateral or multilateral conventions between countries participating in the enhanced cooperation and others (Article 62 of Regulation 2016/1103) must be considered in the choice of applicable law. In Slovenia, international conventions 
will thus be used instead of the ZMZPP in disputes with elements from Hungary, Mongolia, Romania, Poland, or Slovakia. ${ }^{37}$

\subsection{The ratione temporis of Regulation 2016/1103}

In the examples listed above, solutions regarding the application of law depend on whether the ZMZZPP (or the previously valid Croatian ZRSZPDZ) or regulation $2016 / 1103$ is applied. When to apply one or the other depends on the ratione temporis of Regulation 2016/1103, which is determined in the transitional provisions (Article 69).

The regulation applies only to court proceedings ${ }^{38}$ initiated on or after 29 January 2019. If court proceedings were initiated before that date, jurisdiction is subject to national private international law. However, decisions in such procedures (initiated before 29 January 2019) adopted after this date are recognised and enforced in accordance with Regulation 2016/1103 as long as the rules of jurisdiction that have been applied comply with those set out in Regulation 2016/1103. In the examples described above, Regulation 2016/1103 applies for jurisdiction because the proceedings were initiated in (or after) October 2019 (which means on or after 29 January 2019).

The Regulation 2016/1103 rules on the applicable law are applied if the marriage was concluded on or after 29 January 2019. Even when the marriage was concluded before then, Regulation 2016/1103 applies if the spouses agreed on a choice of law applicable to their matrimonial property regime after this date. This is not the case if the spouses (merely) agreed on the international jurisdiction or the applicable matrimonial property regime. This provision was different when Regulation 2016/1103 was adopted in that the conflict-of-law chapter applied to marriages or choice-of-law agreements concluded after 29 January 2019; however, this created a discrepancy with the provision on the application of the remaining chapters of the Regulation. Less than a month after Regulation 2016/1103 was adopted, the Corrigendum to Council Regulation (EU) 2016/1103 of 24 June 2016 implementing enhanced cooperation in the area of jurisdiction, applicable law and the recognition and enforcement of decisions in matters of matrimonial property regimes ${ }^{39}$ was therefore adopted to eliminate the discrepancy. In the above-mentioned cases, the applicable law is thus determined in accordance with Regulation 2016/1103 if the marriage was concluded on or after 29 January 2019. If it was concluded before then, the ZMZPP applies.

Considering the substance of the transitional provisions, it is clear that the national rules on private international law of the Member States participating in the enhanced cooperation will continue to apply in court disputes for a considerable amount of time (as long as there are marriages concluded before 29 January 2019).

37 This is because Slovenia has concluded international agreements in this field with these countries, none of which participate in the enhanced cooperation. See Rudolf, C., op. cit., p. 956.

38 The same applies to authentic instruments and court settlements formally drawn up or registered, approved, or concluded on or after 29 January 2019. 
Example: An Austrian national and a Slovenian national married in 2010 and lived in Austria for three years after that. In 2013 they moved to Slovenia, where they continued living until they divorced in 2019. The ex-wife moved back to Austria and the ex-husband remained in Slovenia. In 2020 she initiated court proceedings for the division of the matrimonial property. Which legal source is applied to determine the international jurisdiction and the applicable law?

Regulation 2016/1103 is applied to determine the jurisdiction in court proceedings initiated on or after 29 January 2019. Pursuant to Article 6/b, jurisdiction will lie with the courts in Slovenia since that is where their last habitual residence was and where the husband continues to reside.

Regulation 2016/1103 is applied for the applicable law if the marriage was concluded on or after 29 January 2019. Given that this condition is not satisfied in this specific case, the applicable law will be determined under the Slovenian ZMZPP using the connecting factor under Article 38/III, which stipulates that the law of the state in which they both had their last permanent residence shall apply - i.e. Slovenian law.

The solution would be different if the applicable law was determined under Regulation 2016/1103, where the connecting factors depend on the time of the conclusion of the marriage. In this case, Article 26/I(a) of Regulation 2016/1103 and Austrian law would apply since the spouses had their first common habitual residence in Austria.

This case illustrates how in practice there will be situations where the jurisdiction is determined under Regulation 2016/1103 and the applicable law under the national rules on private international law. Such a discrepancy will create confusion and will not take advantage of Regulation 2016/1103, which strives to connect both elements (see, e.g., Article 7/I).

\section{MATRIMONIAL PROPERTY RELATIONSHIPS}

The applicable law considerations described above do not apply if the spouses chose the law applicable to their matrimonial property regime before the marriage, at the time of the conclusion of the marriage, or during the course of the marriage (Recital 45). The law they chose applies to all legal issues concerning their matrimonial property (for details, see Article 27 of Regulation 2016/1103). When choosing the law, the spouses may also agree on a specific property regime in the chosen national law; if they do not, the default matrimonial regime provided by the national law applies. ${ }^{40}$ Greater autonomy of the parties gives the spouses more flexibility and improves legal certainty; however, the free will of spouses as regards the choice of law is fairly limited compared to the autonomy of parties in international contract law. ${ }^{41}$ The choice of law by default applies to all assets falling under the matrimonial property regime (Article 21 of Regulation 2016/1103) and the spouses may only choose the law of a state in

40 Oprea, E. A., Party autonomy and the law applicable to the matrimonial property regimes in Europe, Madrid, Cuadernos de Derecho Transnacional, Vol. 10, 2/2018, p. 590.

41 See Regulation Rome I. 
which one or both have habitual residence at the time of the agreement on the choice of law (compare with Article 26/I(a)) or the law of a state of which one of the spouses is a national at that time (compare with Article 26/I(b)).

Connecting a factor to the time of the conclusion of the agreement makes the connecting factor stable notwithstanding potential future change. If the spouses wish to avoid the chosen law in the future, they may change their agreement, which most commonly happens when they have chosen the law of the state of their habitual residence but later moved. It is significantly faster and easier to change habitual residence than it is to change nationality, which represents a more permanent connection and hence longer satisfaction with the chosen law. However, as regards the connecting factor of nationality, there is the question of whether they may choose the law of any state of which they are nationals if one or both of them are nationals of multiple states. Recital 50 of Regulation 2016/1103 explicitly determines that consideration of a person having multiple nationalities falls outside the scope of the regulation and should be left to national law or international conventions, in full observance of the principles of the EU. ${ }^{42}$ For persons with multiple nationalities, the majority of national law arrangements prefer one nationality - typically the nationality of the given state (see above for the regulation thereof in the ZMZPP). The conclusion, then, would be that if one or both spouses have multiple nationalities, they may only choose the law of the state of one of their nationalities as determined by the national law where the agreement is made; thus, nationality and hence the law of the state in which the agreement was concluded have indirect precedence. However, such reasoning contravenes the case law of the CJEU, which emphasises the equality of nationalities. ${ }^{43}$ Such a rule would also require the spouses to ascertain - at the time of concluding the agreement on the choice of law - which law they may choose based on the national provisions of the state in which the agreement is made. This makes it more difficult to conclude an agreement on the choice of law and, due to the lack of clarity, affects legal certainty. On the other hand, inquiries about a preference for a certain nationality over another would allow the spouses to conclude the agreement in a state whose national law would prefer the law of that specific nationality that the spouses may want to choose. By selecting the law of the state under which to conclude the agreement, the spouses would therefore indirectly select the applicable law. There are views in theory ${ }^{44}$ that in applying Recital 50 it is necessary to invoke the provision thereof which refers to "observance of the general principles of the Union" and consider CJEU case law to therefore allow spouses with multiple nationalities to choose the law of any of the states they are nationals of. Another argument speaking in favour of this is the grammatical explanation of Recital 50: it invokes the application of national law when

42 The solution is different in Regulation 650/2012, which explicitly determines the opposite. As the law to govern his or her succession as a whole, a person with multiple nationalities may choose the law of a State whose nationality he or she possesses at the time of making the choice or at the time of death (Article 22).

43 In cases C-369/90, Micheletti, C-148/02, Garcia Avello, and C-168/08, Laszlo Hadadi v. Mesko, the CJEU more or less directly emphasised the equality of all the nationalities a person has.

44 Similar in Oprea, E. A., op. cit., p. 585. 
Regulation 2016/1103 determines nationality as a connecting factor, which is, strictly speaking, not the case when it comes to the choice of law. That is because nationality is not an objective connecting factor that Regulation 2016/1103 invokes per se; it is rather a connecting factor that may be chosen by the spouses. ${ }^{45}$ The conclusion, then, is that Recital 50 does not provide for the situations under Article 22/I(b) of Regulation 2016/1103. Furthermore, another argument in favour of such reasoning, in author's opinion, is the final part of Recital 50, which states that this consideration should have no effect on the validity of a choice-of-law agreement made in accordance with this Regulation. This leads to the conclusion that the reference to national rules from the first part of Recital 50 does not refer to a spousal agreement on the choice of law. If a spouse has multiple nationalities, it is therefore possible to choose the law of any state whose nationality he or she has. ${ }^{46}$

(Future) spouses may select the law of a state in which one of both of them have habitual residence at the time of the conclusion of the agreement, or the law of a state of which one of the (future) spouses is a national at the time of the conclusion of the agreement, but they cannot agree to use the law of the state with which they have the closest connection as of the conclusion of the marriage (see Article 26/I(c)). This makes sense: at the time of the conclusion of the agreement, a vague connecting factor would create uncertainty for the spouses in determining which state they have the closest connection with.

The ZMZPP also limits parties' free will in choosing the applicable law, but in a different way and more narrowly than Regulation 2016/1103. Freedom is allowed only to the extent provided by the law that would apply to their matrimonial property regime (Article 39). The ZMZPP determines that the law applicable to choice-oflaw agreements is determined as of the time the connecting factors are determined. Notwithstanding possible subsequent changes, the connecting factors are determined with regard to the circumstances at the conclusion of the agreement, ${ }^{47}$ which constitutes a sensible connection with the choice-of-law agreement for which the applicable law is determined. Restriction of the parties' autonomy under the ZMZPP thus requires a substantive ruling on the law that would apply to the specific choiceof-law agreement, whereas Regulation 2016/1103 itself specifically determines which law the parties may choose. For spouses who would like to conclude such an agreement, the provisions of Regulation 2016/1103 are significantly simpler and more comprehensible. However, the parties still cannot avoid examining national law rules when concluding an agreement, since they must consider the Regulation's formal requirements with regard to such an agreement. The now invalid ZRSZPDZ (Article 37) required exactly the same.

For the purposes of legal certainty, Regulation 2016/1103 primarily determines that the choice of law applies from the time of the adoption thereof (ex nunc), which

45 See Oprea, E. A., op. cit., p. 585. Similar in Regulation 1259/2010, Recital 22 and Article 5.

46 Similar in Dolžan, J., op. cit., p. 109.

47 This is different for matrimonial property regimes in which (due to the lack of the parties' agreement) the applicable law is determined by assessing the connecting factors (although the connecting factors are the same in both situations - Article 39) at the moment of the initiation of court proceedings. See Section 3. 
may be problematic in practice in the event the agreement is concluded during ${ }^{48}$ the marriage. That is because, for the same property, a matrimonial property regime provided by the substantive law of one state (determined in accordance with Article 26) is used until the agreement is concluded, whereupon the law of the state chosen by the parties applies (and consequently the matrimonial property regime determined therein). To avoid that, Regulation 2016/1103 makes it possible for the spouses to conclude an agreement with retroactive effect, but this may not adversely affect the rights of third parties. ${ }^{49}$

\subsection{Formal requirements}

Aside from the substantive restrictions as to which law the parties may choose, Regulation 2016/1103 also determines the formal requirements that an agreement must satisfy to be valid. This ensures that they are aware of the seriousness of the agreement and its content (Recital 47). The agreement must therefore be expressed in writing, dated, and signed by both parties; any communication by electronic means that provides a durable record of the agreement is deemed equivalent (Article 2016/1103)..$^{50}$ An agreement concluded using customary electronic messages is not valid; if it is made in electronic form, it must be signed by both parties with secure electronic signatures. These are the same requirements that also apply to choice-ofcourt jurisdiction, which is sensible since it is likely that the spouses will agree to the international jurisdiction as well as the conflict-of-law rules in a single document in the event of a matrimonial property dispute. Regulation 2016/1103 provides the same for a (potential) spousal agreement on the matrimonial property regime, whereby it additionally requires fulfilment of the formal requirements provided by the law applicable to the matrimonial property regime (Article 25)..$^{51}$

In addition to the requirements under Regulation 2016/1103 with regard to the validity of the agreement on the choice of law, it is also necessary to consider the potentially stricter national rules of a Member State (participating in the enhanced cooperation) in which both spouses have habitual residence when the agreement is concluded. If their habitual residence is in different states both of which participate in the enhanced cooperation, and the national law of one of them has different formal requirements, the spousal agreement must satisfy the requirements of the law of one of these states. But if only one of the spouses has habitual residence in a Member State participating in the enhanced cooperation, the agreement must satisfy the formal requirements of that Member State. Importantly, the time of the conclusion of the

48 This is not an issue if the spouses select the applicable law before or when concluding the marriage, because it is not until that point that their matrimonial property relationship begins.

49 This issue is beyond the scope of this paper. For details, see Rademacher, L., Changing the past: retroactive choice of law and the protection of third parties in the European regulations on patrimonial consequences of marriages and registered partnerships, Madrid, Cuadernos de Derecho Transnacional, Vol. 10, 1/2018, pp. 14-16.

50 More in Dolžan, J., op. cit., p. 110.

51 Due to the greater possibility of the invalidity of an agreement on matrimonial property, such a role has been criticised by Rudolf, C., op. cit., p. 961. 
agreement is essential in deciding on satisfaction of the requirements, which ensures predictability and legal certainty for the spouses. Regulation 2016/1103 does not lay down special rules if both parties are residents of countries that do not participate in the enhanced cooperation. Absent provisions to the contrary, in such cases only the formal requirements determined by the Regulation itself apply. ${ }^{52}$ Accordingly, spouses with residence in a third country will have to satisfy only the formal requirements of Regulation 2016/1103, whereas if at least one of the spouses has habitual residence in a state participating in the enhanced cooperation, additional requirements may have to be satisfied (provided that conditions stricter than being in written form and signature by the parties are required for the validity of such an agreement). If the requirements are not satisfied, the agreement is invalid and conflict-of-law rules are determined in accordance with Article 26 of Regulation 2016/1103. The explicit nature of the formal requirements therein shows that a silent agreement on the choice of law is not possible. ${ }^{53}$

Spouses who wish to conclude a choice-of-law agreement must first establish which state's formal requirements for the validity thereof they must satisfy. These requirements may well be governed by a different law than that applicable to their agreement (e.g. if they choose the law of a state of which one of them is a national). Despite the provision that the scope of the Regulation excludes the legal capacity of spouses (Article 1/II(a)), consent to and the material validity of the agreement are determined under the law chosen in the choice-of-law agreement. An exception is provided for a situation in which one of the spouses claims he or she did not consent to the choice of law. In such a case, his or her consent and the material validity are determined under the law of the state in which this spouse has habitual residence at the time the court is seised (Article 24/II). ${ }^{54}$ But considering that being in written form and signature by both spouses is required for such an agreement to be valid, such cases will probably not be common..$^{55}$

The first solution (Article 24/I of Regulation 2016/1103) has been criticised in theory because the choice-of-law agreement cannot be examined under the chosen law if it is not proven that the choice was valid, ${ }^{56}$ but this rule is also easily applied by

52 Oprea, E. A., op. cit., pp. 591 and 592, who also has certain qualms about such an arrangement.

53 For an opposite view (albeit on Regulation 2016/1104, which has the same formal requirements as to the validity of choice-of-law agreements), see Rudolf, C., Kolizijske norme Uredbe Sveta (EU) 2016/1104 za premoženjskopravne posledice registriranih partnerskih skupnosti, Ljubljana, Liber Amicorum Ada Polajnar Pavčnik, Razsežnosti zasebnega prava, p. 276.

54 The same in Article 10 of Regulation Rome I.

55 Oprea, E. A., op. cit., p. 590, lists as a possible example a situation in which the agreement is written in a language that one of the spouses does not speak and the provisions on consent and the material validity of the agreement are different in the chosen law and in the law of the state in which the spouse has habitual residence.

56 Grieco, C., The role of party autonomy under the regulations on matrimonial property regimes and property consequences of registered partnerships. Some remarks on the coordination between the legal regime established by the new regulations and other relevant instruments of European private international law. Madrid, Cuadernos de Derecho Transnacional, Vol. 10, 2/2018, p. 475 . 
the parties,${ }^{57}$ and it is provided in certain other EU regulations as well. ${ }^{58}$ The second solution (Article 24/I of Regulation 2016/1103) has been the subject of some criticism in theory as well. A spouse who wishes to malevolently dispute his or her consent to the choice-of-law agreement may intentionally change his or her residence so that at the time the court is seised it will apply the national law whose provisions regarding the validity of consent suits this spouse. There have therefore been suggestions that it may be more appropriate to instead examine the validity of consent at the time it was provided. ${ }^{59}$ However, the court nevertheless determines in each specific case which circumstances must exist to conclude that the effects of such spousal action should be examined according to the selected law.

\subsection{Change of a choice-of-law agreement}

Spouses may subsequently dissolve or change a choice-of-law agreement due to a change in life circumstances. Even though Regulation 2016/1103 does not explicitly provide that, dissolution triggers a new choice-of-law procedure under Article 26 thereof. The Regulation also does not determine when or for what reason the agreement may be dissolved. The conclusion, then, is that the spouses may decide to change the applicable law before or when concluding the marriage, or during the marriage. They may decide that - notwithstanding their original choice of law and choice of connecting factor - what is important is that in making a new choice of law they use the connecting factors and consider the formal requirements as provided by Regulation 2016/1103; in author's opinion, in doing so they are not restricted by any specific conditions or requirements that national law may provide with regard to changes in the choice-of-law agreement. The newly chosen law applies as of the time the choice-of-law agreement is concluded; during the validity of the original agreement the matrimonial property is subject thereto, and before that it may fall under the law determined by Article 26 of Regulation 2016/1103. In practice, such cases will cause problems when different laws apply to matrimonial property in different time periods. This can be avoided with an agreement as to the ex tunc validity of the new choiceof-law agreement (application by analogy of Article 22/II) ${ }^{60}$ Such an agreement may, however, cause problems in that it might affect rights acquired under one matrimonial property regime that a spouse would no longer have under the matrimonial property regime in the newly agreed upon applicable law. It is also necessary to be mindful of third parties, which enjoy protection under the above-mentioned Articles 22/I and $28 / \mathrm{I}$.

57 Oprea, E. A., op. cit., p. 590.

58 Cf. Article 3/V in conjunction with Article 10/I of Regulation Rome I, Article 6/I of Regulation Rome III, Article 22/III of Regulation 650/2012 on succession.

59 Oprea, E. A., op. cit., p. 590.

60 For concerns about this, see Oprea, E. A., op. cit., p. 594. 


\section{EXCLUSION OF RENVOI}

In invoking foreign law, differences in conflict-of-law rules may create problems when conflict-of-law rules refer back or forward, whereupon one of the subsequent laws refers to a law that had already been considered. The question, then, is whether in the event of reference to the application of a foreign law such foreign law is used in its entirety - its conflict-of-law rules included - or whether only substantive law applies. The Slovenian ZMZPP and the now invalid Croatian ZRSZPDZ both include renvoi provisions. ${ }^{61}$ They both stipulate in their respective Article 6 that the conflict-of-law rules of the referenced national law must be applied. But if the referenced law refers back, the substantive provisions of the referenced law are directly applicable. ${ }^{62}$ The Croatian ZMPP, on the other hand, excludes renvoi, ${ }^{63}$ just like Regulation 2016/1103. When Regulation 2016/1103 refers to the application of a national law (even of a state not participating in the enhanced cooperation or not a member of the EU - Article 20), this entails that the substantive law of such state must be applied, excluding the rules of private international law of that state (Article 32). ${ }^{64}$ The only exceptions are the incompatibility of the law of the state with the public policy of the country in which the procedure is ongoing (Article 31) and explicit permission to apply the overriding mandatory provisions ${ }^{65}$ of the law of the forum (Article 30).

\section{IN PLACE OF A CONCLUSION}

If the matrimonial property regime ultimately falls under the purview of Slovenian substantive law, it is necessary to keep in mind a new legal arrangement. As of 15 April 2019 , matrimonial property is subject to the Family Code. ${ }^{66}$ The legal arrangement ${ }^{67}$ therein remains the same compared to the previous Marriage and Family Relations Act (Zakon o zakonski zvezi in družinskih razmerjih) ${ }^{68}$ with one essential difference: (future) spouses (as well as cohabiting partners and registered or unregistered partners)

61 Similarly in Regulation 650/2012 - cf. Article 31.

62 For details, see Geč Korošec, M., Mednarodno ..., Prva ..., cit., pp. 109 et seq.

63 It provides certain exemptions, but matrimonial property regimes are not one of them (Article 9 of the ZMPP).

64 The same in Regulation Rome III - cf. Article 11.

65 Recital 53 of Regulation 2016/1103 determines that mandatory provisions must be interpreted strictly so they remain compatible with the overriding goal of the Regulation. One such example is the protection of the family home, which enjoys special protection by the mandatory provisions of the state in which the procedure is ongoing (Recital 53). In Slovenian law, such a mandatory provision on the protection of the family home is provided by Article 59 of the Family Code. From Dougan, F., Nova evropska pravila o pristojnosti, pravu, ki se uporablja, ter priznavanju in izvrševanju odločb na področju premoženjskih razmerij mednarodnih parov, Ljubljana, Liber Amicorum APP, 2019, p. 243, and Novak, B, Družinski zakonik z uvodnimi pojasnili, Ljubljana, Uradni list, 2017, p. 72.

66 OG RS15/17 as amended.

67 The available legal arrangements are the community property regime for common property and the separate property regime for the personal property of each spouse (Article 66 of the Family Code).

68 OG SRS $15 / 76$ as amended. 
may conclude an agreement on matrimonial property ${ }^{69}$ (the simpler yet not entirely correct terms "nuptial agreement" 70 and "prenuptial agreement" are commonly used in practice). In doing so, they may choose the law (including foreign law) applicable to their matrimonial property and settle all matrimonial property issues for the duration of their union and in the event of divorce. ${ }^{71}$ The spouses may thus partially or entirely circumvent the validity of the statutory matrimonial property regime and completely independently devise a matrimonial property regime applicable to them, whereby the Family Code does not describe or list possible matrimonial regimes. ${ }^{72}$ Such an agreement must be entered into a register. The legal arrangement, ${ }^{73}$ and in particular the public nature of the information contained in such agreements, has, however, become a subject of public criticism and there are already discussions underway indicating that it may be changed. ${ }^{74}$

\section{BIBLIOGRAPHY}

Books:

1. Geč Korošec, Miroslava, Mednarodno zasebno pravo, Prva knjiga - splošni del, Ljubljana, Uradni list Republike Slovenije, 2001.

2. Geč Korošec, Miroslava, Mednarodno zasebno pravo, Druga knjiga - posebni del, Ljubljana, Uradni list Republike Slovenije, 2002.

3. Ilešič, Marko, Polajnar Pavčnik, Ada, Wedam Lukić, Dragica, Mednarodno zasebno pravo, komentar zakona, Ljubljana, Uradni list Republike Slovenije, 1992.

4. Novak, Barbara, Družinski zakonik z uvodnimi pojasnili, Ljubljana, Uradni list Republike Slovenije, 2017.

5. Novak, Barbara (ed.), Komentar Družinskega zakonika, Ljubljana, Uradni list Republike Slovenije, 2019.

6. Scherpe, J. M. (ed.), Marital Agreements and Private Autonomy in Comparative Perspective, Oxford, Hart Publishing, 2012.

Articles:

1. Damascelli, Domenico, Applicable law, jurisdiction, and recognition of decisions in matters relating to property regimes of spouses and partners in European and Italian private international law, Trusts \& Trustees, vol. 0, 0/2018, pp. 1-11.

69 On why the term is inappropriate, see Žnidaršič Skubic, V., Pogodba o ureditvi premoženjskopravnih razmerij med zakoncema, Ljubljana, Podjetje in delo, Vol. XLIV, 6-7(2018), pp. 920 and 921.

70 Žnidaršič Skubic, V. and Erjavec, N., in Novak, B. (ed.), Komentar Družinskega zakonika, Ljubljana, Uradni list Republike Slovenije, 2019, p. 261.

71 For details on the content of such an agreement, see Žnidaršič Skubic, V. and Erjavec, N., in Novak, B. (ed.), Komentar ..., cit., pp. 263-265 and 273.

72 This is a subject of criticism in theory of law. See Žnidaršič Skubic, V., in Novak, B. (ed.), Komentar ..., cit., p. 187 and Žnidaršič Skubic, V., Pogodba o ureditvi premoženjskopravnih razmerij med zakoncema, Ljubljana, Podjetje in delo, Vol. XLIV, 6-7(2018), pp. 925-926.

73 Comment by Žnidaršič Skubic, V. and Erjavec, N., in Novak, B. (ed.), Komentar ..., cit., p. 267 and Podgoršek, B., in Novak, B. (ed.), Komentar ..., cit., pp. 284-287 and 299.

74 E.g. https://www.vecer.com/razgalili-pare-ki-so-sklenili-predporocno-pogodbo- 10041102 (accessed 13 August 2019), https://www.rtvslo.si/slovenija/zakaj-so-podatki-o-tem-kdo-jepodpisal-zenitno-pogodbo-javni/495241 (accessed 14 August 2019). 
2. Dolžan, Judita, Uredbi (EU) glede premoženjskopravnih razmerij za mednarodne pare kolizijska pravila, Ljubljana, Odvetnik, vol. 90, 2/2019, pp. 106-113.

3. Dougan, Filip, Nova evropska pravila o pristojnosti, pravu, ki se uporablja, ter priznavanju in izvrševanju odločb na področju premoženjskih razmerij mednarodnih parov, Liber Amicorum Dragica Wedam Lukić, Ljubljana, 2019, pp. 233-247.

4. Grieco, Cristina, The role of party autonomy under the regulations on matrimonial property regimes and property consequences of registered partnerships. Some remarks on the coordination between the legal regime established by the new regulations and other relevant instruments of European private international law, Madrid, Cuadernos de Derecho Transnacional, vol. 10, 2/2018, pp. 457-476.

5. Kunda, Ivana, Novi međunarodnoprivatnopravni okvir imovine bračnih i registriranih partnera u Europskoj uniji: polje primjene i nadležnost, Zagreb, Hrvatska pravna revija, vol. 19, 3/2019, pp. 27-36.

6. Poretti, Paula, Odlučivanje o imovinskim odnosima bračnih drugova u ostavinskim postupcima sukladno Uredbi 2016/1103 o bračnoimovinskom režimu, Rijeka, Zbornik Pravnog fakulteta Sveučilišta u Rijeci, vol. 38, 1/2017, pp. 449-474.

7. Rademacher, Lukas, Changing the past: retroactive choice of law and the protection of third parties in the European regulations on patrimonial consequences of marriages and registered partnerships, Madrid, Cuadernos de Derecho Transnacional, vol. 10, 1/2018, pp. 7-18.

8. Rudolf, Claudia, Kolizijske norme Uredbe Sveta (EU) 2016/1104 za premoženjskopravne posledice registriranih partnerskih skupnosti, Liber Amicorum Ada Polajnar Pavčnik, Razsežnosti zasebnega prava, Ljubljana, pp. 265-279.

9. Rudolf, Claudia, Premoženjska razmerja med zakonci v mednarodnem zasebnem pravu, Ljubljana, Podjetje in delo, vol. XLIV, 6-7/2018, pp. 952-963.

10. Marino, Silvia, Strengthening the European civil judicial cooperation: the patrimonial effects of family relationships, Madrid, Cuadernos de Derecho Transnacional, vol. 9, 1/2017, pp. 265-284.

11. Oprea, Elena Alina, Party autonomy and the law applicable to the matrimonial property regimes in Europe, Madrid, Cuadernos de Derecho Transnacional, vol. 10, 2/2018, pp. 579-596.

12. Schulz, Rhona, Choice of law in relation to matrimonial property in the 21 st Century, Journal of Private International Law, vol. 15, 1/2019, pp. 1-49.

13. Valentová, Lucia, Property regimes of spouses and partners in new EU Regulations jurisdiction, prorogation and choice of law, De Gruyter, ICLR, vol. 16, 2/2016, pp. 221240.

14. Žnidaršič Skubic, Viktorija, Pogodba o ureditvi premoženjskopravnih razmerij med zakoncema, Ljubljana, Podjetje in delo, vol. XLIV, 6-7/2018, pp. 917-928.

Internet sources:

1. Ruggeri, Lucia, Kunda, Ivana, Winkler, Sandra (eds.), Family Property and Succession in EU Member States National Reports on the Collected Data, $<$ https://www.euro-family.eu/ documenti/news/psefs_e_book_compressed.pdf> (1 August 2019)

National legal acts:

Croatia

1. Act Concerning the Resolution of Conflicts of Laws with the Provisions of Other Countries in Certain Matters (Zakon o rješavanju sukoba zakona s propisima drugih zemalja u ođređenim odnosima), OG Croatia 53/91 and 88/01.

2. Private International Law Act (Zakon o međunarodnom privatnom pravu), OG Croatia $101 / 17$. 
Slovenia

1. Act Concerning the Resolution of Conflicts of Laws with the Provisions of Other Countries in Certain Matters (Zakon o ureditvi kolizije zakonov s predpisi drugih držav v določenih razmerjih), OG SFRJ 43-525/82 as amended.

2. Family Code (Družinski zakonik), OG RS $15 / 17$ as amended.

3. Marriage and Family Relations Act (Zakon o zakonski zvezi in družinskih razmerjih), OG SRS $15 / 76$ as amended.

4. Private International Law and Procedure Act (Zakon o mednarodnem zasebnem pravu in postopku), OG RS 56/99 as amended.

\section{International legal acts:}

1. Corrigendum to Council Regulation (EU) 2016/1103 of 24 June 2016 implementing enhanced cooperation in the area of jurisdiction, applicable law and the recognition and enforcement of decisions in matters of matrimonial property regimes OJ EU L 183 of 8 July 2016.

2. Council Decision (EU) 2016/954, OJ L 159/16 of 16 June 2016.

3. Council Regulation (EU) 2016/1104 of 24 June 2016 implementing enhanced cooperation in the area of jurisdiction, applicable law and the recognition and enforcement of decisions in matters of the property consequences of registered partnerships, OJ EU L 183 of 8 July 2016.

4. Council Regulation (EU) 2016/1103 of 24 June 2016 implementing enhanced cooperation in the area of jurisdiction, applicable law and the recognition and enforcement of decisions in matters of matrimonial property regimes, OJ EU L 183 of 8 July 2016.

5. Council Regulation (EU) No. 1259/2010 of 20 December 2010 implementing enhanced cooperation in the area of the law applicable to divorce and legal separation (Regulation Rome III), OJ L 343/10 of 29 December 2010.

6. Regulation (EC) No. 593/2008 of the European Parliament and of the Council of 17 June 2008 on the law applicable to contractual obligations (Regulation Rome I), OJ L 177 of 4 July 2008.

7. Regulation (EU) No 650/2012 of the European Parliament and of the Council of 4 July 2012 on jurisdiction, applicable law, recognition and enforcement of decisions and acceptance and enforcement of authentic instruments in matters of succession and on the creation of a European Certificate of Succession, OJ L 201 z dne 27. julija 2012.

8. Regulation (EC) No. 1896/2006 of the European Parliament and of the Council of 12 December 2006 creating a European order for payment procedure, OJ EU L 399 of 30 December 2006.

Case law:

1. C-168/08 of 16 July 2009, Laszlo Hadadi (Hadady) v. Csilla Marta Mesko, épouse Hadadi (Hadady).

2. C-369/90 of 7 July 1992, Mario Vicente Micheletti and others v. Delegación del Gobierno en Cantabria.

3. C-148/02 of 2 October 2003, Carlos Garcia Avello v. Belgian State. 


\section{Neža Pogorelčnik Vogrinc*}

Sažetak

\section{MJERODAVNO PRAVO U BRAČNOIMOVINSKIM SPOROVIMA}

Ovaj članak predstavlja mjerodavno pravo utvrđeno u Uredbi Vijeća (EU) 2016/1103 od 24. lipnja 2016. o provedbi pojačane suradnje u području nadležnosti, mjerodavnog prava te priznavanja i izvršenja odluka u stvarima bračnoimovinskih režima. Dolazi se do zaključka da je nova europska Uredba olakšala bračnim drugovima određenje mjerodavnog prava te se vrednuje primjerenost povezujućih čimbenika predviđenih u Uredbi. Rad dovodi u pitanje te povezujuće čimbenike u trenutku zaključenja braka i pretpostavlja da ih je teško isključiti u izvanrednim okolnostima. Ti se čimbenici uspoređuju s onima iz teorije slovenskog i hrvatskog međunarodnog privatnog prava, a u radu se nude praktični primjeri za razlike proizašle iz novog europskog uređenja. U radu se nadalje istražuje hipoteza da će mogućnost sporazuma o izboru mjerodavnog prava u praksi prouzročiti probleme te se za to nude moguća rješenja. U cijelom se radu uspoređuje sustav uveden Uredbom Vijeća (EU) 2016/1103 s drugim europskim uredbama i relevantnom sudskom praksom Suda Europske unije, ali se autorica ponajviše usredotočuje na promjene koje je navedena Uredba donijela u slovensko i hrvatsko pravo.

Ključne riječi: bračnoimovinski režim; mjerodavno pravo; Uredba (EU) 2016/1103; međunarodno privatno pravo; sporazum o izboru mjerodavnog prava.

\section{Zusammenfassung}

\section{ANZUWENDENDES RECHT BEI STREITIGKEITEN ÜBER DEN EHELICHEN GUTERSTAND}

Dieser Beitrag stellt das in der Verordnung (EU) 2016/1103 des Rates vom 24. Juni 2016 zur Durchführung einer Verstärkten Zusammenarbeit im Bereich der Zuständigkeit, des anzuwendenden Rechts und der Anerkennung und Vollstreckung von Entscheidungen in Fragen des ehelichen Güterstands festgelegte anzuwendende Recht dar. Man kommt zu der Schlussfolgerung, dass die neue EU-Regelung es den Ehepartnern erleichtert hat, das anzuwendende Recht zu bestimmen, und bewertet die

* Dr. sc. Neža Pogorelčnik Vogrinc, docentica, Pravni fakultet Sveučilišta u Ljubljani; neza. pogorelcnik@pf.uni-lj.si. 
Eignung der in der Verordnung (EU) 2016/1103 vorgesehenen Anknüpfungspunkte. Der Beitrag stellt diese Anknüpfungspunkte zum Zeitpunkt des Abschlusses der Ehe in Frage und geht davon aus, dass deren Ausschließen unter außergewöhnlichen Umständen schwer zu erreichen ist. Der Beitrag vergleicht diese Anknüpfungspunkte mit denen, die in der Theorie des slowenischen und des kroatischen internationalen Privatrechts angeboten werden, und liefert praktische Beispiele für die Unterschiede, die sich aus der neuen europäischen Regelung ergeben. Der Beitrag untersucht ferner die Hypothese, dass die Möglichkeit der Rechtswahlvereinbarung in der Praxis viele Probleme bereiten wird, und stellt dafür mögliche Lösungen dar. Im gesamten Beitrag wird das mit der Verordnung (EU) 2016/1103 eingeführte System mit anderen europäischen Verordnungen und der einschlägigen Rechtsprechung des EuGH verglichen. Die Autorin konzentriert sich jedoch hauptsächlich auf die Änderungen der slowenischen und kroatischen Rechtsprechung, die durch die Anwendung der Verordnung (EU) 2016/1103 verursacht wurden.

\title{
Schlüsselwörter: ehelicher Güterstand; anzuwendendes Recht; Verordnung (EU) 2016/1103; internationales Privatrecht; Rechtswahlvereinbarung.
}

\author{
Riassunto
}

\section{LA LEGGE APPLICABILE NELLE DISPUTE RIGUARDANTI IL REGIME PATRIMONIALE TRA CONIUGI}

Nel lavoro si presenta la disciplina concernente la legge applicabile come dettata dal Regolamento (UE) 2016/1103 del Consiglio, del 24 giugno 2016, che attua la cooperazione rafforzata nel settore della competenza, della legge applicabile, del riconoscimento e dell'esecuzione delle decisioni in materia di regimi patrimoniali tra coniugi. Se ne ricava che le nuove soluzioni europee hanno reso per i coniugi più semplice determinare la legge applicabile. Nel lavoro si valuta altresì la sostenibilità dei criteri di collegamento offerti dal Regolamento 2016/1103. Inoltre mediante l'indagine condotta si tenta la disamina di criteri di collegamento, quali il tempo di conclusione del matrimonio e si conclude come la loro esclusione in circostanze eccezionali sia difficile da realizzare. Nel contributo si paragonano altresì i criteri di collegamento con quelli previsti dal diritto internazionale privato sloveno e da quello croato nella teoria; inoltre, si offrono esempi pratici delle differenze risultanti dalle nuove soluzioni prospettate sul piano europeo. Nel prosieguo si disamina l'ipotesi che la possibilità di accordo circa la scelta della legge applicabile potrebbe causare molte questioni nella prassi e si offrono possibili soluzioni. Nel corso dell'indagine condotta il sistema fissato dal Regolamento 2016/1103 viene comparato con altri regolamenti, come anche con la giurisprudenza della Corte di Giustizia dell'UE; benché l'autore in 
primo luogo si concentra sui cambiamenti nella giurisprudenza slovena ed in quella croata occorsi con l'entrata in vigore del Regolamento 2016/1103.

Parole chiave: regime patrimoniale tra coniugi; legge applicabile; Regolamento 2016/1103; diritto internazionale privato; accordo sulla legge applicabile. 
